Hosay Trinidad 
This page intentionally left blank 


\section{Hosay Trinidad}

Muharram Performances in an Indo-Caribbean Diaspora

FRANK J . KOROM

\section{$\overline{\text { PENN }}$}

University of Pennsylvania Press Philadelphia 
Copyright (C) 2003 University of Pennsylvania Press

All rights reserved

Printed in the United States of America on acid-free paper

$\begin{array}{llllllllll}10 & 9 & 8 & 7 & 6 & 5 & 4 & 3 & 2 & 1\end{array}$

Published by

University of Pennsylvania Press

Philadelphia, Pennsylvania 19104-401 I

Library of Congress Cataloging-in-Publication Data

Korom, Frank J.

Hosay Trinidad : muharram performances in an Indo-Caribbean diaspora / Frank J. Korom.

p. cm.

Includes bibliographical references and index.

ISBN 0-8122-3683-1 (alk. paper)-ISBN 0-8122-1825-6 (pbk. : alk. paper)

1. Tenth of Muharram. 2. Shi'ah-Customs and practices. 3. Shi'ah-Trinidad and Tobago. 4. Muslims-Trinidad and Tobago. 5. Trinidad and Tobago-Religious life and customs. I. Title.

BP194.5.T4 K67 2002

$297.3^{\prime} 6-\mathrm{d} c 21$

2002075894 